\title{
Diversification of Renewable Energy Sources Utilizing Eceng Gondok Eichhornia crassipes in Microbial Fuel Cells
}

\author{
Maswati Baharuddin ${ }^{1}$, Heri heriyono ${ }^{2}$, Sappe wali ${ }^{3}$, Ummi Zahra $^{4}$ \\ ${ }^{1,2,3,4}$ Department of Chemistry, Faculty of Science and Technology, Universitas Islam Negeri \\ Alauddin Makassar, Indonesia. 92113 \\ \{bmaswati@gmail.com¹, heriyono640@gmail.com²,wali_assa@yahoo.co.id ${ }^{3}$,zahraummi@gmail.com ${ }^{4}$.
}

\begin{abstract}
Microbial Fuel Cell (MFC) was a Technology that produced electrical energy utilizing microorganism. The purpose of this study was to know enceng gondok potency as substrate in MFC system and add electrolyte solution and buffer. This study used enceng gondok as substrate and Pseudomonas sp. bacteria. The Method of this study was using double compartment that consist of anode and cathode chambers. Both of them were related by salt bridge. The result showed that electric current and potential differences maximum that was produced (without added of electrolyte solution and buffer) was $0.11 \mathrm{~mA}$ and $0,27 \mathrm{~V}$ while power density was $20.34 \mathrm{~mW} / \mathrm{m} 2$. Whereas Electrolyte solution and buffer combination showed electric current and potential differences maximum that produced was $3.06 \mathrm{~mA}$ and $0.86 \mathrm{~V}$ while power density yaitu $1802.46 \mathrm{~mW} / \mathrm{m} 2$.
\end{abstract}

Keywords: Phosphate Buffers, Eceng Gondok, Electrolytes, Microbial Fuel Cell (MFC).

\section{Introduction}

Microbial fuel cells (MFCs) are an emerging technology that directly converts the chemical energy stored in organic matter to electricity. Energy was produced some sustrate which was glucose, acetate, butrate, laktate, ethanol and cellulose(Yazdi, et al., 2011: 278-283). Enceng gondok was organic material that easy growth at water area. It was high rate to growth so its existence in nature was very abundant. Enceng gondok contained high cellulose which was $64,51 \%$, lignin 7,69\% and other organic material (Moeksin, dkk., 2016: 10). It is very potencial was used as substrate in MFC system. Baharuddin et All (2015:59) reported that cellulose in plant has potency to change became simply sugar by cellulotic bacteria. The sugar could is used as carbon resources and nutrition at bacteria growth. The use of Bacteria related to MFC system condition. Electrolyte solution and buffer on appropriate condition would increase electric potency that produced. Muftiana et all (2018) reported that tofu water waste substrate with Lactobaccillus bulgarius used electolite solution $\mathrm{KMnO}_{4} 0,2 \mathrm{M}$ produced higher electrical potency which was $99,2 \mathrm{mV}$ than $\mathrm{K}_{3}\left[\mathrm{Fe}(\mathrm{CN})_{6}\right]$ which is $48,6 \mathrm{mV}$. Beside eletrolite solution and buffer influenced to efficiency and energy potency. They influenced to microorganism growth condition. (Fitriani et All ( 2018:76). Based on it, this study aimed to diversification of renewable energy sources utilizing enceng gondok as substrate and Pseudomonas $S p$ bacteria at MFC basic technology. To Produce high electric potency, so was used vary of electrolyte 
solution and buffer. Combination that used at electrolyte solution which was $\mathrm{KMnO}_{4}$ 0,2 $\mathrm{M}$ dan $\mathrm{K}_{3} \mathrm{Fe}(\mathrm{CN})_{6} 0,2 \mathrm{M}$ and

Sodium fosfate and kalium fosfate as buffer solution.

\section{Material and Methods}

This study uses a MFC 5 compartment double system, each system consists of $2500 \mathrm{~mL}$ spaces connected by a bridge to make $\mathrm{KCl} 0.1 \mathrm{M}$. One space functions as an anode chamber filled with $350 \mathrm{~mL}$ of water hyacinth pulp and another space filled with $350 \mathrm{~mL}$ of aquades, 350 $\mathrm{mL}$ of $\mathrm{KMnO}_{4} 20.2 \mathrm{M}$, and $\mathrm{K}_{3} \mathrm{Fe}(\mathrm{CN})_{6} 0.2 \mathrm{M}$ functions as a cathode chamber. In the anode and cathode chambers, graphite electrodes are inserted which are activated with $1 \mathrm{M} \mathrm{HCl}$ solution and $1 \mathrm{M} \mathrm{NaOH}$ for 1 day and copper wire is placed on the top of the electrode. Then $5 \mathrm{~mL}$ of bacteria is inserted into the anode chamber with the addition of $10 \mathrm{~mL}$ buffer solution Sodium phosphate and Potassium Phosphate buffer using a pipette volume, the type of bacteria used is Pseudomonas Sp. Furthermore, current measurements and potential differences using a digital multimeter every 4 hours for 36 hours so that the maximum point is obtained, then calculated the value of power density.

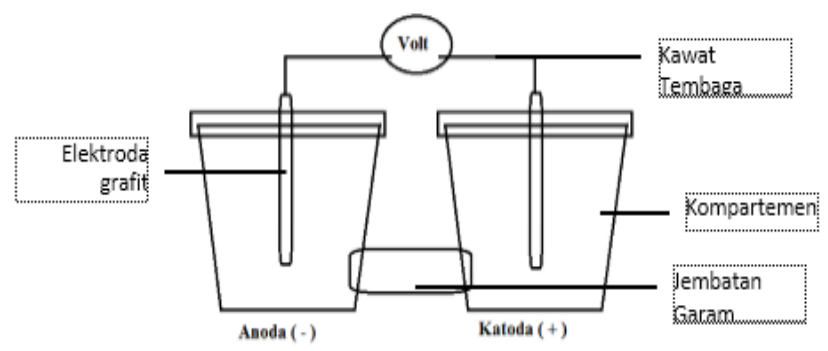

Fig 1. double compartment design (Sumber: Logan, 2006)

\section{Results and Discussion}

In this research, current measurements and potential differences in water hyacinth susbtrat were carried out to determine the effect of adding two types of electrolyte solutions, namely $\mathrm{KMnO} 40.2 \mathrm{M}$ and $\mathrm{K} 3 \mathrm{Fe}(\mathrm{CN}) 60.2 \mathrm{M}$ in the cathode chamber. Also used were variations of buffer solution in the anode chamber, namely buffer sodium phosphate $\mathrm{pH} 7$ and potassium phosphate buffer $\mathrm{pH} 7$, knowing the suitable buffer solution in maintaining the environmental $\mathrm{pH}$ condition of Pseudomonas Sp on water hyacinth substrate and at the same time knowing the appropriate combination between the use of electrolyte solution and buffer material in produce maximum current and potential difference.

The current and potential difference without the addition of electrolytes and buffers are shown in Figure 1. During the 0 to 20 hours there is a pattern of decreases and increases in currents so that the resulting current is not stable. This is because, the substrate used is cellulose, the bacteria must break down cellulose into glucose first (Ibrahim et al, 2014).

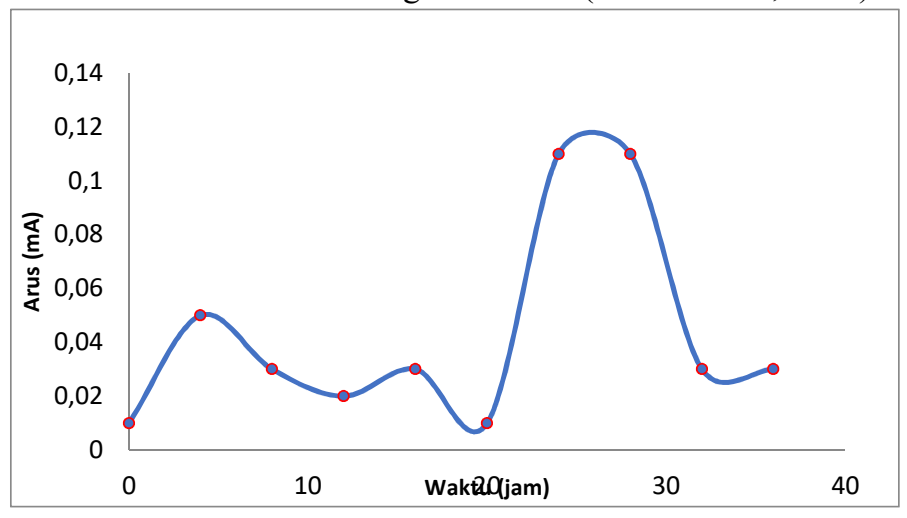


Fig 1. Flow of water hyacinth substrate without the addition of electrolytes and buffers

The metabolic process starts at the 20th to the 24th hour, after which at the 28th hour the maximum current indicates the peak phase of cell division. Then at the 32 nd to 36 th hours it shows a decrease pattern followed by a relatively constant current pattern. This pattern of decreasing current indicates that bacteria are already in the phase of death.

The maximum current obtained from the water hyacinth substrate without additions is 0.11 $\mathrm{mA}$. The current value produced in this study is higher than the current value obtained by Purwono, et al. (2015) which uses substrate from tofu industry wastewater which is equal to $7.25 \mu \mathrm{A}$. The value of electric current generated in the MFC system is due to bacterial activity that carries out metabolic processes on the substrate and the ability of MFC as energy conversion. Bacterial activity that occurs can be seen from the increase in the value of current generated from the amount of nutrients from the substrate consumed (Kristin, 2012).

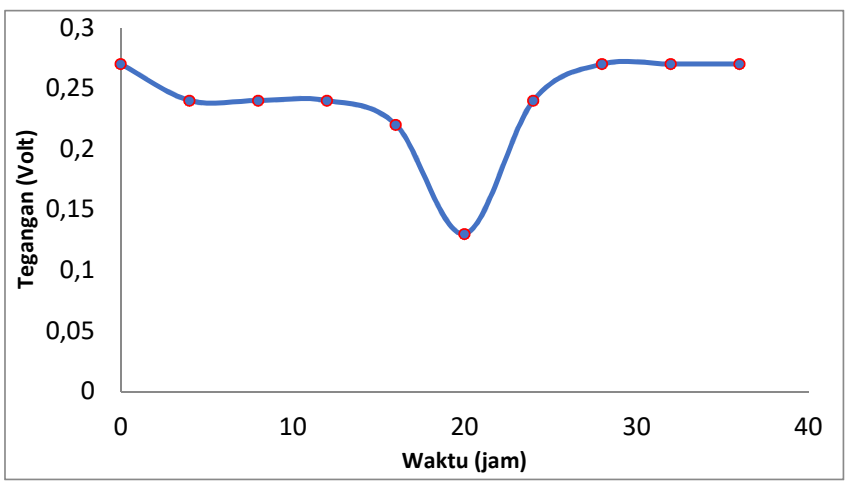

Fig 2. Potential difference of water hyacinth substrate without the addition of electrolytes and buffers

Figure 2 shows the potential difference value of the maximum 28th to 36th hour, which is equal to $0.27 \mathrm{~V}$. On the 4 th to 12 th hours the potential difference is constant, which is $0.24 \mathrm{~V}$. 16 to 20 shows a pattern of decline in potential differences. On the 24th to the 36th hour the pattern of increase in potential difference was followed by a relatively constant potential difference value.

The maximum potential difference obtained in this study is higher than the research conducted by Inayati, et al. (2015) which uses a substrate from glucose that is equal to $24.3 \mathrm{mV}$. However, Kurniawati and Sanjaya (2013) research using cellulose fibers from cattle rumen with the addition of Pseudomonas Sp produced a higher potential difference of $750 \mathrm{mV}$. This is caused by cellulose fibers originating from the cattle rumen which contain many cellulotic bacteria which are capable of breaking down cellulose fibers (Omed, et al., 2000). So that the use of the appropriate type of bacteria in the MFC system can also affect the energy produced.

To be able to increase the current and potential difference in the MFC system, the addition of a variety of electrolyte solutions with phosphate buffer material is used. The results of current measurements are shown in Figure 3.

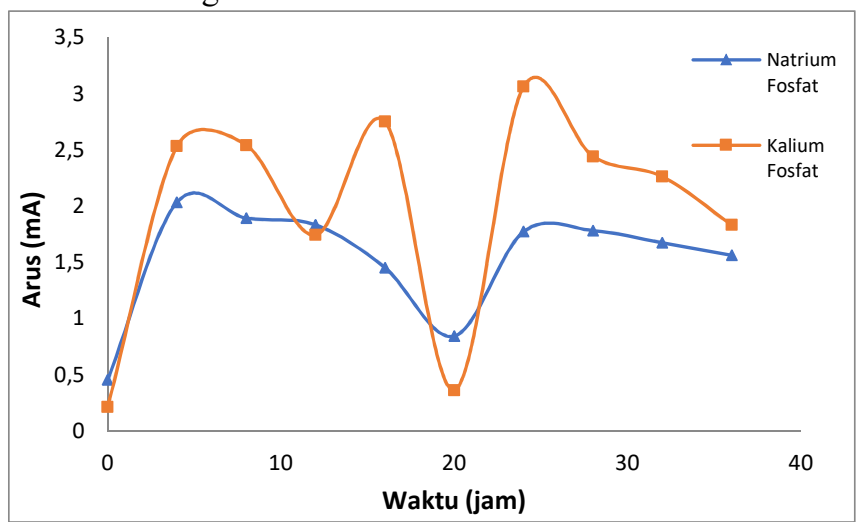


Fig 3. Flow of $\mathrm{KMnO}_{4}$ with variations of the buffer material Sodium phosphate and potassium phosphate

In Figure 3, it can be seen that there is a difference in the flow produced from the combination of electrolyte $\mathrm{KMnO} 4$ with a buffer material of sodium phosphate and potassium phosphate buffer. The combination with a potassium phosphate buffer solution results in a higher average flow compared to the sodium phosphate buffer solution. Potassium phosphate buffer produces a maximum current value of $3.06 \mathrm{~mA}$, while sodium phosphate buffer is 2.03 $\mathrm{mA}$.

In addition, the occurrence of a pattern of increase and decrease in the flow produced at 0 o'clock to 20 o'clock, is due to the activity of bacteria in the decomposition of complex compounds into simpler molecules (Ibrahim et al, 2014) and the occurrence of competitive interactions between bacteria in the growth substrate.

Figure 4 shows the maximum potential difference of the 0th hour and 36th hour, which is equal to $0.40 \mathrm{~V}$ for sodium phosphate buffer. Potassium phosphate buffer, which is equal to 0.86 $\mathrm{V}$, is indicated at the 0th, 12th, 20th and 24th hours. Based on Sari's research, et al. (2016) which used a variation of buffer material and $\mathrm{pH}$ on whey tofu flour with Lactobacilus bulgarius showed that potassium phosphate buffer also produced a higher potential difference of $42.2 \mathrm{mV}$. But in this study the current obtained was higher due to the high content of cellulose fiber from water hyacinth. So that the carbon source needed by the bacteria in the process of metabolism is more and the energy produced is high.

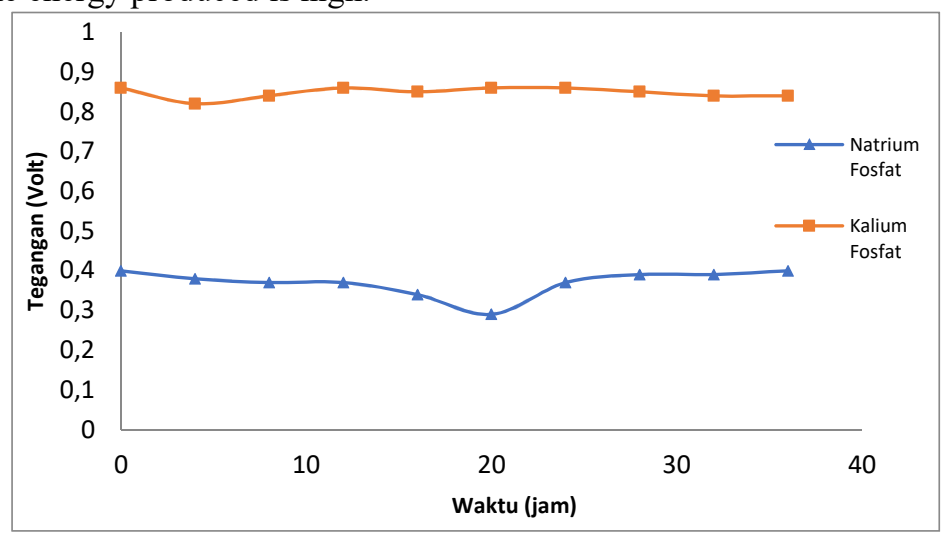

Fig 4. Potential difference of $\mathrm{KMnO}_{4}$ with variations of buffer material Sodium phosphate and potassium phosphate

To find out the effect of adding electrolyte solution types with variations of the buffer solution combination on the electrical energy produced, then the addition of $\mathrm{K} 3 \mathrm{Fe}(\mathrm{CN}) 60.2$ M electrolyte solution in the MFC system and potassium and sodium phosphate buffer solutions. The results of current measurements and potential differences are shown in Figures 5 and 6.

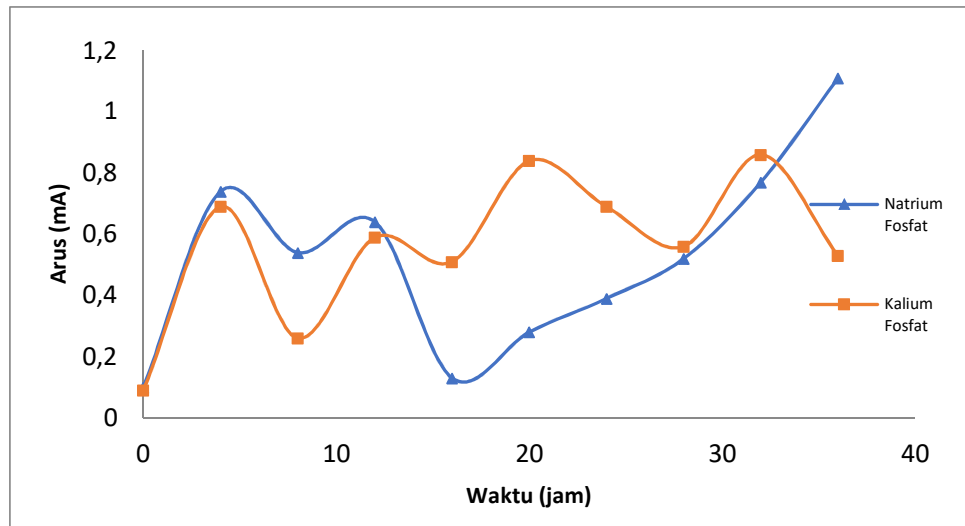


Fig 5. Current value of $\mathrm{K}_{3} \mathrm{Fe}(\mathrm{CN})_{6}$ with a variation of the sodium phosphate and potassium phosphate buffer material

Figure 5 shows that the combination of a $\mathrm{K} 3 \mathrm{Fe}(\mathrm{CN}) 6$ electrolyte solution with a potassium phosphate buffer produces a higher average current compared to a combination of a $\mathrm{K} 3 \mathrm{Fe}(\mathrm{CN})$ 6 electrolyte solution with a sodium phosphate buffer. However, the maximum current value obtained using sodium phosphate buffer is higher at $1.11 \mathrm{~mA}$, while for potassium phosphate is $0.86 \mathrm{~mA}$.

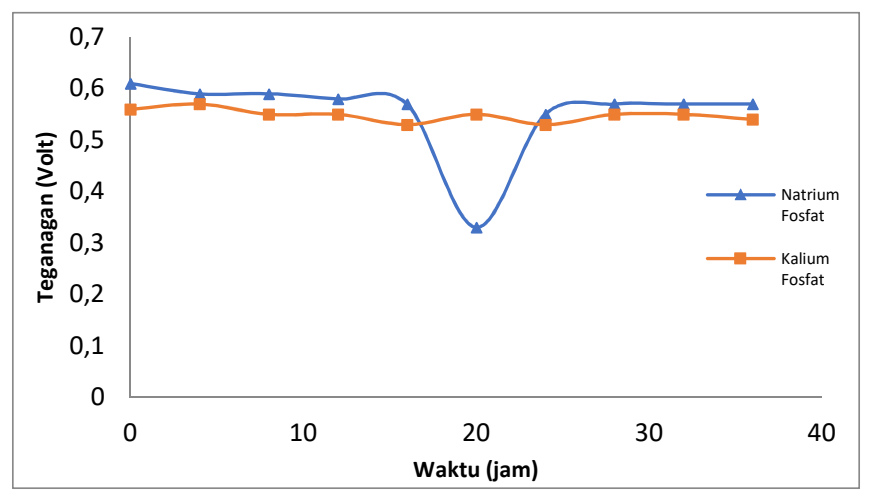

Figure 6. Potential difference of $\mathrm{K}_{3} \mathrm{Fe}(\mathrm{CN})_{6}$ with variations of the buffer material Sodium phosphate and potassium phosphate

In Figure 6, the potential difference is relatively constant, only at the 20th hour, that is, sodium phosphate shows a sharp decrease in potential difference that is equal to $0.33 \mathrm{~V}$. After experiencing a sharp pattern of decline, again shows an increase in current followed by a pattern relatively constant. Unlike the measurement of current values, at this potential difference value the use of sodium phosphate buffer material produces a high average value compared to potassium phosphate material. The maximum potential difference value produced is equal to $0.61 \mathrm{~V}$ to buffer sodium phosphate and $0.57 \mathrm{~V}$ for potassium phosphate buffer.

In the Muftiana study, et al (2018) which used a variation of the concentration of electrolyte solution $\mathrm{K} 3 \mathrm{Fe}(\mathrm{CN}) 60.25 \mathrm{M} ; 0.2 \mathrm{M} ; 0.15 \mathrm{M} ; 0.1 \mathrm{M}$ and $0.001 \mathrm{M}$ obtained the maximum potential difference at a concentration of $0.2 \mathrm{M}$ which is equal to $48.6 \mathrm{mV}$. Based on this study, the potential difference is higher because the addition of variations in phosphate buffer $\mathrm{pH} 7$ is more suitable for the $\mathrm{pH}$ of the Pseudomonas Sp environment so that the energy produced is higher.

Based on the maximum current value and potential difference in each combination of electrolyte solution with phosphate buffer material. Then the value of the efficiency of Power Density $(\mathrm{mW} / \mathrm{m} 2)$ is calculated, which is power per unit of electrode surface area. The highest value of Power Density $(\mathrm{mW} / \mathrm{m} 2)$ is the combination of KMnO4 electrolyte solution with potassium phosphate buffer of $1802.46 \mathrm{~mW} / \mathrm{m} 2$. Maminska, et al. (2018) who used cellulose substrates obtained Power Density values of $44 \mathrm{~mW} / \mathrm{m} 2$.

From the results obtained that the value of Power Density using a water hyacinth substrate produces a higher Power Density $(\mathrm{mW} / \mathrm{m} 2)$. This is presumably because $\mathrm{KMnO} 4$ has a 
standard reduction potential value of $1.70 \mathrm{~V}$ compared to $\mathrm{K} 3 \mathrm{Fe}(\mathrm{CN}) 6 \neg$ with the price of reduction potential of $0.36 \mathrm{~V}$. Thus, the use of electrolyte solutions with the addition of suitable buffer materials can affect the current value, potential difference and the value of Power Density $(\mathrm{mW} / \mathrm{m} 2)$ produced by the MFC system.

\section{Conclusion}

The results of measurements of water hyacinth substrate on the MFC system produce a maximum current and potential difference value $0.27 \mathrm{~mA}$ dan $0.11 \mathrm{~V}$. From the use of a combination of electrolyte solutions, a $0.2 \mathrm{M} \mathrm{KMnO}_{4}$ solution with a potassium phosphate buffer solution yielded a higher current, potential difference and Power Density value of 3.06 $\mathrm{mA} ; 0.86 \mathrm{~V}$ and $1802.46 \mathrm{~mW} / \mathrm{m}^{2}$.

As for the sara in this study is the need for the preparation of MFC methods do fiber water hyacinth through mechanical and chemical treatment. Mechanical treatment is done to further minimize the size of the fibers, whereas chemical treatment to eliminate the rate of lignin and hemicellulose contained in water hyacinth.

\section{References}

[1] Baharuddin, Maswati., Patong, A. R., Ahmad, A., Nafie, N. L. "Isolasi dan Karakterisasi Bakteri Simbion Larva Kupu-Kupu Cossus cossus Penghasil Enzim Selulase". Al-Kimia (2015): h. 58-68.

[2] Ibrahim, B., P. Suptijah dan S, Rosmalawati. "Kinerja Rangkaian Seri Sistem Microbial Fuel Cell Sebagai Penghasil Biolistrik Dari Limbah Cair Perikanan. Jurnal JPHPI 17, no. 1 (2014).

[3] Inayati, N, S., Aminin, Agustina L. N dan Suyati, Linda. "The Bioelectricity of Tofu Whey in Microbial Fuel Cell System With Lactoacillus Bulgarius". Jurnal Sains dan Matematika 23, no. 1 (2015): h. 32-38.

[4] Kurniawati, Laili dan Sanjaya, I, Gusti, Made. "Pengaruh Jenis Bakteri Selulotik Terhadap Efisiensi Sel Bakar Mikroba". Unesa Journal Of Chemistry 2, no. 2 (2013): h. $17-22$.

[5] Logan, Bruce E and Regan, John M. "Electricity-Producting Bacterial Comunities in Microbial Fuel Cell”. Elselvier 14, no. 12 (2006): h. 512-518.

[6] Moeksin, Rosdiana., Comeriorensi, Liliana., dan Damayanti, Rita. "Pembuatan Bioetanol Dari Eceng Gondok (Eichornia Crassipes) dengan Perlakuan Fermentasi". Journal Teknik Kimia 22, no. 1 (2016): h. 19-17.

[7] Muftiana, Ilmi., Suyati, L., dan Widodo, D. S. "The Effect of KMnO4 and $\mathrm{K} 3[\mathrm{Fe}(\mathrm{CN}) 6]$ Concentrations on Electrical Production in Fuel Cell Microbial System with Lactobacillus bulgaricus Bacteria in a Tofu Whey Substart". Jurnal Kimia Sains dan Aplikasi 21, no. 1 (2018): h. 49-53.

[8] Nurhamida. "Optimasi Produksi Inokulan Pseudomonas Sp. dan Viabilitasnya dalam Bahan Pembawa Gambut". Skripsi. Bogor: Departemen Biologi Fakultas MIPA Institut Pertanian Bogor, 2009.

[9] Omed, H. M., D. K. Lovert, and R. F. E. Axford. Feces as a Source of Microbial Enzymes for Estimating Digesfibility. I: Forage Evaluation in Ruminant Animal Digestive Physiology and Nutrition. C.A.B.I. Publishing New York, 2000.

[10] Purwono., Hermawan., Hardianto. "Penggunaan Teknologi Reaktor Microbial Fuel Cell (MFC) Dalam Pengolahan Limbah Cair Industri Tahu Untuk Menghasilkan Energi Listrik". Jurnal Presipitasi 12, no. 2 (2015): h. 57-65. 
[11] Rismani-Yazdi, Hamid., Chirty, Ann D., Dehority Burk A., Morrison, Mark., Yu, Zhongtang., and Touvinen, Olli H. "Electricity Generation From Cellulose by Rumen Microorganisms in Microbial Fuel Cell". Biotechnology and Bioengineering 97, no. 6 (2007): h. 1398-1407.

[12] Sitorus, B. "Diversivikasi Sumber Energi Terbarukan Melalui Penggunaan Air Buangan dalam Sel Elektrokimia Berbasis Mikroba”. Jurnal ELKHA 2, no. 1 (2010): h. 10-15. Kristin, Ester. "Produksi Energi Listrik Melalui Microbial Fuel Cell (MFC) Menggunakan Limbah Industri Tempe". Skripsi. Depok: Fakultas Teknik Program Studi Teknologi Bioproses Universitas Indonesia, 2012.

[13] Suyati, L., Fitriani, F. Z., dan Rahmanto, W. H. "Pengaruh Konsentrasi Substrat Maltosa terhadap Potensial Listrik Baterai Lactobacillus bulgaricus (MFC)”. Jurnal Kimia Sains dan Aplikasi 20, no. 2 (2017): h. 74-78.

[14] Rubin, E M.”Genomic Of Cellulose Biofuels". Nature, vol. 4, pp. 841-845, 2008.

[15] Razaei, Farzaneh, Xing, Defeng, Wagner, Rachel, Regan J M, Richard, T L, Logan B E. "Simultaneous Cellulose Degradation and Elektricity Production by Enterobacter cloacae in a Microbial Fuel Cell”. Applied and Environmental Microbiology, vol. 11, pp. 3673-3678, 2009.

[16]Ren, Z., E. Ward, Thomas., and Regan, John. M. "Electricity Production From Cellulose in a Microbial Fuel Cell Using a Defined Binary Culture". Environmental Science and Technology 41, no. 13 (2007): h. 4781-4786. 